\title{
Influence Management of School Heads and Teacher Learning Media Towards Student Achievement
}

\author{
Sutrisno ${ }^{1 *}$, NurAhyani ${ }^{2}$, Syaiful Eddy ${ }^{2}$
}

\author{
${ }^{1}$ SD Negeri 1 Air Putih Ulu \\ ${ }^{2}$ Universitas PGRI Palembang \\ *Corresponding author. Email: sutrisnoapul@gmail.com
}

\begin{abstract}
The goal of this study is to evaluate the impact of key management and teaching learning media on student achievement in SD Negeri Plakat Tinggi Subdistrict. This research uses quantitative methods and types of correlational research. The technique of collecting data using a questionnaire. Analysis of research results using multiple regression analysis. The findings showed that: (1) principal management had an impact on student achievement in SD Negeri Plakat Tinggi Subdistrict; (2) the effect of teaching media on student achievement in SD Negeri Plakat Tinggi Subdistrict, and (3) the main management and teaching media effect on student achievement in SD Negeri Plakat Tinggi Subdistrict.
\end{abstract}

Keywords: Principal Management, Learning Media, Student achievement

\section{INTRODUCTION}

Seeing the conditions in the Plakat Tinggi Subdistrict Elementary School, Musi Banyuasin District, both the achievement achievements and school managerial management in general have not run optimally. The results of empirical studies regarding the performance of school principals in basic education institutions are generally still not as expected. The determination of qualifications has not been fully followed by managerial and entrepreneurial skills. The school principal has not been able to formulate strategic school planning for various functions, either human resources or educational services. The Principal should be capable of carrying out inventions, be able to guide all stakeholders and the school as an education institution [1]. School development has not been adapted to the needs of both internal and external customers. School leadership has not encouraged intellectual growth in order to optimize school resources. Leadership changes towards effective learning organizations have not yet been implemented, especially in schools that have weak support, especially in resources. Principal must be tough in carrying out his responsibilities in order to increase the standard of education services [2]. The implementation and management of educational institutions in schools cannot be distinguished from the position of school principals as a determining factor in the performance of good governance in education. The principal is the manager of human resources in schools where human resources are the main factor that determines the success of an organization because human resources drive other resources. As a leader, the Principal becomes a promoter of the school community, in particular teachers, whose direction is directed at achieving the vision, mission and goals of the school community [3]. Human resources can create value at the intersection between the strategy implementation system, including in formal educational institutions. Teacher who has competent in his field will have a more positive impact on the development of students to understand the subject matter [4]. The efforts to improve the human resources are an integrated effort in improving the quality of education [5].

Understanding Learning Media, Sadiman [6] notes that the word media originates from Latin and is the plural form of the word medium, which simply means intermediary or introduction. Association of Education and Communication Technology (AECT) in America, limits the media as any form and channel that people use to transmit messages / information. According to Sadiman [6] learning tool, it has a tangible definition that is currently known as hardware, one that can be seen, heard or touched by sensory senses. Active learning has a non-physical sense recognized as software, which is the content of the message found in the hardware that is the information to be transmitted to pupils. Teachers are a profession whose job is to carry 
out primary and secondary education by using a range of learning methods to fulfill their learning objectives [7].

The concentration of teaching materials is on visual and audio. From this interpretation, it can be assumed that learning media involves helping both inside and outside the classroom in the learning process. Learning media is used in the form of contact and interaction between educators and pupils in the education process. Management comes from the verb to manage, which means to manage, organize, implement, and manage. This understanding indicates that management is a technique to regulate, therefore in management it is necessary to regulate the elements contained in the elements of management (man, money, methods, machines, materials, and market), what are the objectives in regulating, why must be regulated, who governs, and how to organize it. Principal management is an activity in the execution of its tasks and functional units that is owned by the leadership of the organization [8]. The Principal has the authority and policies to enhance the standard of education as a leader [9]. The leader referred to in this research is the principal as a leader who regulates and leads in an educational institution or school.

\section{METHODS}

Table 1. Characteristics of respondents based on gender

\begin{tabular}{cccccc}
\hline & & Frequency Percent & $\begin{array}{c}\text { Valid } \\
\text { Percent }\end{array}$ & $\begin{array}{c}\text { Cumulative } \\
\text { Percent }\end{array}$ \\
\hline Valid & Male & 19 & 19 & 19 & 100 \\
& Female & 81 & 81 & 81 & 100.0 \\
& Total & 100 & 100.0 & 100.0 & \\
\hline
\end{tabular}

(Source: Data processed by SPSS, 2020)

Referring to table, it seems to be that the genderbased characteristics of the respondents are 19 with a percentage of $19 \%$ and 81 with a percentage of 81
Methodology is a determining factor for the merits of writing scientific papers [10]. This approach used in this study is descriptive in terms of quantity and correlation. Correlational analysis, the purpose of which is to clarify the causal relationship and the hypothesis testing. The context for this study is the independent variable $(\mathrm{X})$ and the dependent variable $(\mathrm{Y})$, namely the Principal Management (X1), Learning Media (X2), and Student Achievement (Y). The primary data used in this study is a questionnaire distributed to respondents who are teachers and principals of SD Negeri in Plakat Tinggi Subdistrict. Secondary data. In the present analysis is the report of the teacher information gathered from the Regional Coordinator of the Higher Education Education and Culture Plakat Tinggi. In addition, researchers also use books, journals and theses as reference materials. To answer the problem formulation data collection techniques using techniques: interview, documentation, questionnaire, observation.

\section{RESULTS AND DISCUSSION}

\section{1) Respondent Profile}

The characteristics of the respondents in this research include gender, age, education, duration of work and income: females. In order to provide a better picture of the characteristics of participants on the basis of gender, it can be seen in the image below:

Table 2. Statistical descriptive analysis

\begin{tabular}{|c|c|c|c|c|c|c|c|c|}
\hline & $\mathrm{N}$ & Range & Minimum & Maximum & \multicolumn{2}{|l|}{ Mean } & \multirow{2}{*}{$\begin{array}{l}\text { Std. Deviation } \\
\text { Statistic }\end{array}$} & \multirow{2}{*}{\begin{tabular}{|l} 
Variance \\
Statistic
\end{tabular}} \\
\hline & Statistic & Statistic & Statistic & Statistic & Statistic & Std. Error & & \\
\hline Management of School Heads & 100 & 26 & 70 & 96 & 80.84 & .508 & 5.083 & 25.833 \\
\hline Learning Media & 100 & 23 & 72 & 95 & 82.27 & .474 & 4.744 & 22.502 \\
\hline Student Achievement & 100 & 23 & 71 & 94 & 82.51 & .517 & 5.169 & 26.717 \\
\hline Valid N (listwise) & 100 & & & & & & & \\
\hline
\end{tabular}

(Source: Data processed by SPSS, 2020)

Description of Principal Management Variable Data The detailed description of the Principal Management variable for public elementary school teachers in the SD Negeri Plakat Tinggi Subdistrict, Musi Banyuasin 
district based on the absolute criteria that have been set

can be seen in the table as follows:

Table 3. Description of Principal Management variable data

\begin{tabular}{|c|c|c|c|c|}
\hline No & Interval & Criteria & Frequency & Percentage \\
\hline 1 & $90-100$ & $\begin{array}{l}\text { Very } \\
\text { good }\end{array}$ & 5 & 5 \\
\hline 2 & $70-89$ & Good & 95 & 95 \\
\hline 3 & $50-69$ & $\begin{array}{l}\text { Pretty } \\
\text { good }\end{array}$ & 0 & 0 \\
\hline 4 & $30-49$ & $\begin{array}{l}\text { Not } \\
\text { good }\end{array}$ & 0 & 0 \\
\hline 5 & $20-29$ & $\begin{array}{l}\text { Not } \\
\text { good }\end{array}$ & 0 & 0 \\
\hline \multicolumn{3}{|c|}{ Total } & 100 & $100 \%$ \\
\hline
\end{tabular}

(Source: Data processed by SPSS, 2020)

\section{2) Normality Prerequisite Test}

The normality test is performed for evaluate whether or not the independent variable and dependent variable have a normal distribution in the regression model. The data normality test can be performed using One Sample
Kolmogorov Smirnov, given that if the significant value is greater than 0.05 , the data is normally distributed. In the meantime, if the results of One Sample Kolmogorov Smirnov indicate a significant value below 0.05 , the data is not usually distributed. The effects of the normality test are shown in the table below:

Table 4. One-Sample Kolmogorov-Smirnov Test

\begin{tabular}{|c|c|c|c|c|}
\hline & & $\begin{array}{l}\text { Managem } \\
\text { ent of } \\
\text { School } \\
\text { Heads }\end{array}$ & $\begin{array}{l}\text { Learning } \\
\text { Media }\end{array}$ & $\begin{array}{l}\text { Student } \\
\text { Achieve } \\
\text { ment }\end{array}$ \\
\hline \multicolumn{2}{|l|}{$N$} & 100 & 100 & 100 \\
\hline \multirow{2}{*}{$\begin{array}{l}\text { Normal } \\
\text { Parameters }^{a, t}\end{array}$} & Mean & 80.42 & 81.88 & 82.51 \\
\hline & $\begin{array}{l}{ }^{b} \text { Std. } \\
\text { Deviation }\end{array}$ & 5.298 & 5.217 & 5.169 \\
\hline \multirow{3}{*}{$\begin{array}{l}\text { Most } \\
\text { Extreme } \\
\text { Differences }\end{array}$} & Absolute & .086 & .087 & .072 \\
\hline & Positive & .086 & .087 & .072 \\
\hline & Negative & -.053 & -.065 & -.067 \\
\hline \multicolumn{2}{|c|}{ Test Statistic } & .086 & .087 & .072 \\
\hline \multicolumn{2}{|c|}{ Asymp. Sig. (2-tailed) } & $.063^{\mathrm{c}}$ & $.060^{c}$ & $200^{\mathrm{c}, \mathrm{d}}$ \\
\hline
\end{tabular}

a. Test distribution is Normal.

b. Calculated from data.

c. Lilliefors Significance Correction.

$d$. This is a lower bound of the true significance.

Based on the table above, it can be seen that the probability coefficient (sig) for Principal Management is .063 or $6.3 \%$, Learning Media is .060 or $6 \%$ and the Student Achievement value is .200 or $20 \%$, after consulting the $\mathrm{p}$ value> $0,05(5 \%)$. Thus, the data can be said that the variables of Principal Management, Learning Media, and Student Achievement are normally distributed, so the analysis in this study can be used. The plot graph shows that the data is normally distributed can be seen in the image below: 


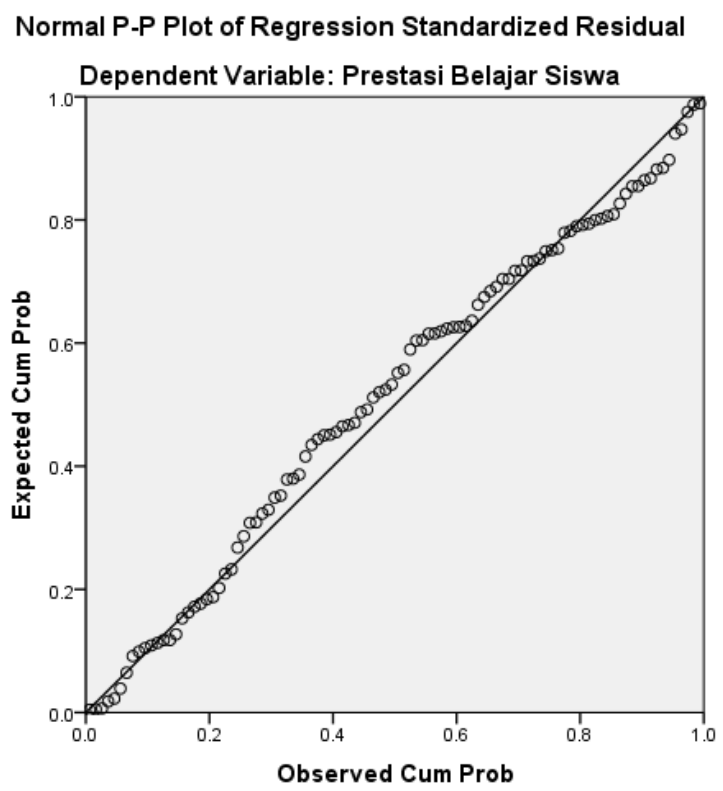

Figure 1. Normality Test Results

Based on the image above, it can be shown that the plot points in the image often follow the diagonal lines. As an up what is known making in the probability plot methodology normality test, it can also be inferred that the residual process is normally allocated.

\section{3) Heteroscedasticity Test}

The objective of the heteroscedasticity test is to test if there is an inequality of variance between the residues of one observation and another in the regression model. One way to detect the presence or absence of heteroscedasticity is by looking at the plot graph between the expected value and the residual value. The basis for the analysis is (1) If there is a pattern (wavy, expanded, then narrowed) then it means that heteroscedasticity has occurred and (2) If there is no pattern, the point spreads above and below the number 0 on the $\mathrm{Y}$ axis, then heteroscedasticity does not occur. The findings of the heteroscedasticity test are shown in the following figure:

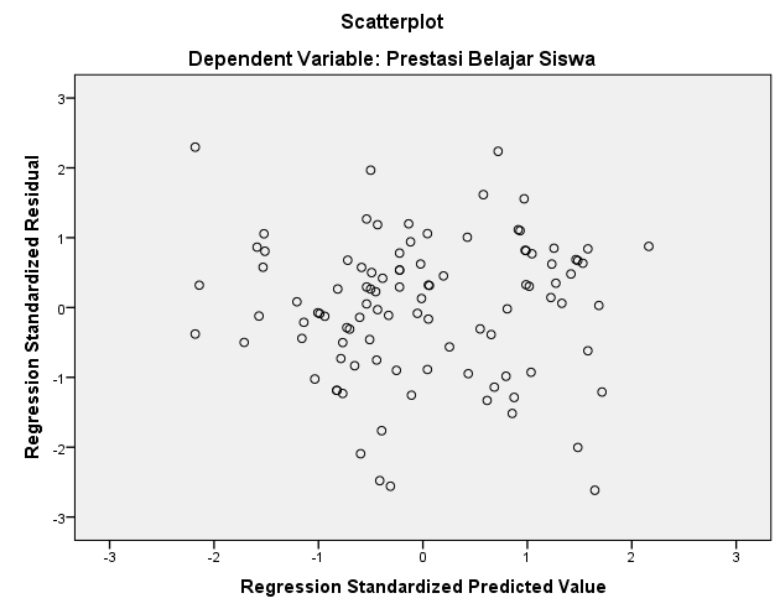

Figure 2. Heteroscedasticity Test 
The results of the principal management linearity test on student learning achievement.

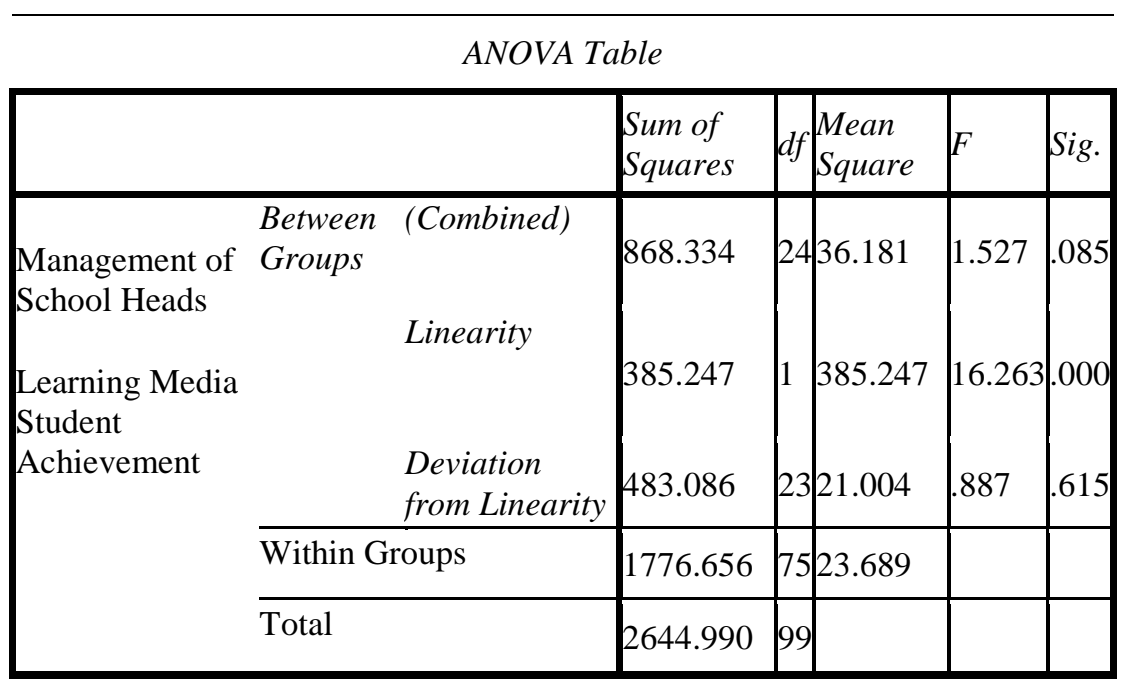

(Source: Data processed by SPSS, 2020)

Principal Management greatly contributed to improving the Student's Learning Achievement. Learning Media also contributes to improving Student Learning Achievement because with good Learning Media, student learning achievement will increase Based on the description of the research results and discussion regarding the Effect of Principal Management and Learning Media in the Plakat Tinggi Subdistrict, it can be concluded as follows: Principal management has a positive and significant effect on student achievement in SD Negeri Plakat Tinggi Subdistrict, learning media has a negative and significant effect on student achievement in SD Negeri Plakat Tinggi Subdistrict and Principal management and learning media have a positive and significant effect on student achievement in SD Negeri Plakat Tinggi Subdistrict.

Based on the findings that Principal Management contributed positively to Student Learning Achievement, Learning Media contributed positively to Student Learning Achievement, and Principal Management and Learning Media together had a positive effect on Student Achievement of SD Negeri in Plakat Tinggi Suddistrict. Even so, there is a need for consideration efforts that can be input for interested parties to continue to improve Student Learning Achievement in improving quality, especially education in Plakat Tinggi Subdistrict. The suggestions are as follows; 1 . The findings of this study can be used as material for consideration for the Department of Education and Culture of Musi Banyuasin Regency in policy making and coaching in elementary schools related to Head Management, learning media infrastructure and student learning achievement.

\section{CONCLUSION}

Departure Based on the findings of the Hypothesis Testing, the following conclusions can be drawn: 1) there is a positive and important effect of this Principal Management variable on the Learning Achievement of Students is $14.6 \%$, and the remaining $85.4 \%$ is determined by other causes outside the regression model or influenced by other factors outside of this study; 2) there is a positively significant impact on student achievement between Learning Media by 35\%, and the remaining $65 \%$ is determined by other causes outside the regression model or influenced by other factors outside of this research, and 3) there is a positively significant impact of the Head Management and Learning Media variables together on Student Achievement of SD Negeri in Plakat Tinggi Subdistrict, Musi Banyuasin Regency and the Head Management and Learning Media variables have a joint effect on Student Achievement of SD Negeri in Plakat Tinggi Subdistrict Musi Banyuasin District is $38 \%$, and the remaining $62 \%$ is determined by other causes outside the multiple regression model or influenced by other factors outside of this study.

\section{REFERENCES}

[1] Andriani, S., Kesumawati, N., \& Kristiawan, M. (2018). The Influence of the Transformational Leadership and Work Motivation on Teachers Performance. International Journal of Scientific \& Technology Research, 7(7).

[2] Zulaiha, D., Lian, B., \& Mulyadi. (2020). The Effect of Principal's Competence and Community Participation on the Quality of Educational Services. Journal of Social Work and Science Education Volume 1 (1) E-ISSN: 2723-6919. 
[3] Suratman, S., Arafat, Y., \& Eddy, S. (2020). The Influence of Principal's Leadership and Teacher's Competence toward Teacher's Performance in Indonesia. Journal of Social Work and Science Education, 1(2), 96-104. Retrieved from https://ejournal.karinosseff.org/index.php/jswse/arti cle/view/32

[4] Budiyono, Lian, B., \& Fitria, H. (2020). The Influence of Principal Supervision and Organizational Climate toward Teacher's Performance. Electronic Research Journal of Social Sciences and Humanities Vol 2: Issue II.

[5] Tobari., Kristiawan, M. \& Asvio, N. (2018). The Strategy of Headmaster on Upgrading Educational Quality in Asean Economic Community (AEC) Era. International Journal of Scientific \& Technology Research 7 (4).

[6] Sadiman, R., Haryono \& Rahardjito. (2008). Media Pendidikan, Pengertian, Pengembangan dan Pemanfaatannya [Media Education, Understanding, Development and Utilization]. Jakarta: PT Raja Grafindo Persada.

[7] Rahmadoni, J., Arifnur, A. A., \& Wahyuni, U. M. (2020). Penerapan Schoology Sebagai Learning Management System Bagi Guru SMAN 1 Sutera [Implementation of Schoology as a Learning Management System for Teachers of SMAN 1 Sutera]. Jurnal Hilirisasi IPTEKS volume 3 No 2.

[8] Ghozali, I. (2016). Aplikasi Analisis Multivariate dengan Program SPSS [Multivariate Analysis Application with SPSS Program]. Semarang: BPFE UNDIP.

[9] Asvio, N., Yamin, M., \& Risnita. (2019). Influence of Leadership Style, Emotional Intelligence and Job Satisfaction toward Organizational Commitment (Survey at SMA Muhammadiyah South Sumatera). International Journal of Scientific \& Technology Research 8 (8).

[10] Muttaqin, K., \& Rahmadoni, J. (2020). Analysis and Design of File Security System AES (Advanced Encryption Standard) Cryptography Based. Journal of Applied Engineering and Technological Science (JAETS), 1(2), 113-123. https://doi.org/10.37385/jaets.v1i2.78 